\title{
液晶を用いた光沢除去のための視覚システム
}

$\begin{array}{llllll}\text { 正員 山 } & \text { 田 } & \text { 啓 } & \text { 一 } & \text { (豊田中研) } \\ \text { 非会員 } & \text { 中 } & \text { 野 } & \text { 倫 } & \text { 明 } & \text { (豊田中研) } \\ \text { 正 員 山 } & \text { 本 } & & \text { 新 } & \text { (豊田中研) }\end{array}$

\section{A Vision System for Removal of Specular Reflection Component Using a Liquid Crystal}

Keiichi Yamada, Member, Tomoaki Nakano, Non-member, Shin Yamamoto, Member (Toyota Central Res. \& Develop. Labs. Inc.)

A problem in realizing a vehicle which autonomously travels along a guide line on the floor in an in-plant environment by its vision is the gloss of the floor which obstructs the recognition of the line. The gloss is caused by interface reflection from object surfaces.

This paper proposes a method to obtain images of an interface reflection component and a body reflection component when the shape of object surfacs is known. This method is based on the Dichromatic Reflection Model and utilizes the difference in Fresnel reflection coefficient between parallel and perpendicular components of polarization. No knowledge on the number and disposition of light sources is required. A vision system based on this method has been developed using a liquid crystal cell and its performance was examined. By applying this system to the vision of a vehicle, the guide line was found to be reliably recognized from the image of the body reflection component even if the floor was glossy due to illuminations. Thus, the effectiveness of the proposed method wan confirmed.

キーワード: 偏光, 光沢, 除去, 2 色性反射モデル, 波晶, 自律走行車

\section{1. まえがき}

画像処理技術の進歩を背景に, 生産工程に扔ける計 測や検査の自動化は大幅に進み(1)，視覚をつ自律走 行車の開発も活発化している(2)。しかし，これらの検 奋や認識対象はほとんどが拡散反射を主体とした対象 物で，鏡面反射を含む光沢のある物体を対象にしたも のではない。

しかしながら，現実の生産工程などでは，プラスチ ックや磨加れた金属の上うに, 光沢のある対象物が多 数あり,これらの対象物を認識したり検査することが できないのが現状(3)である。

構内を白線に治って走行寸る視賞付き自律走行車で も，太陽光が差し込んだり天井照明で走行路面が光つ たりした場合には，光沢の影響により路面の白線を確
実に検出することができない。このような環境の下で も白線を検出できるようにするには, 路面が光沢をも つ場合でもその影響を受けずに安定な画像が撮像でき ることが必要である。

光沢のある物体を撮像して認識する代表的な方法に は，偏光を用いた方法(4)(5)，反射モデルを利用した方 法(6K(7), 光度差ステレオ法(8)(9), パターン光を投影す る方法(10)(11)，などがある。

Shafer ${ }^{(6)} ら は$, 反射光が表面反射成分と内部反射成 分とからなるとする 2 色性反射モデルを提案し，この うち表面反射成分が光沢として認識などに影響を及ほ すとしている。彼らは, この 2 色性反射モデルに基づ き, 反射光の RGB 空間での色べクトル分布から表面 反射成分を分離した。しかし、これを実現するために は, カラー画像が必要であるう光，その認識処理も複 
雑であるので，白律走行車の視賞への適用は難しい。

また，白井ら (9)の光度差ステレオ法では透過型の面 光源を, 藤村ら ${ }^{(10)}$ の方法では $M$ 配列符号化光源を, 越川ら (4)の偏光を利用した方法では円偏光光源を，そ れぞれ必要とする。このようにいずれの方法も特殊な 条件を満たした光源で物体を照明する必要があるた め，自律走行車への応用には適していない。

著者らの方法は, 特殊な条件を満たした照明を必要 とすることなく，反射光の表面反射成分と内部反射成 分去分離して，その内部反射成分だけを抽出して光沢 のある白線でも安定に撮像しようとするものである。 この原理を用いて液晶を利用した視覚システムを実現 し，これを自律走行車の視覚に応用して良好な結果を 得たので報告する。

本論女では，第 2 章で偏光による除去の方法を，第 3 章でこの原理に基づく視賞ジステムを，第 4 章でそ の性能評価実験を，そして第 5 章では，自律走行車の 視賞への応用について述べ。

\section{2. 偏光による除去方式}

〈2・1〉原理この原理は，表通反射率が入 射光の偏光方向によって異なることを利用して，反射 光を表面反射成分と内部反射成分に分離するものであ る。ここで，対象物体での反射が 2 色性反射モデル(6) で表されること，および反射光の内部反射成分は非偏 光であることを仮定している。

图 1 に入射光 $I$ と反射光 $L$ との間の入射角 $i$ ，反 射角 $e$, 位相 $g$ および面の法線 $N$ の定義を示す。入 射角が $i て ゙$ て長が $\lambda$ の入射光に対する反射角 $e$ ，位相 角 $g$ の反射光の强度を $L(\lambda, i, e, g)$ で表す。反射光 $i$ は，電界の振動面が法線 $N$ と反射光 $L$ を含亩に平 行な成分 ( $p$ 成分) と，それに垂直な成分 ( $s$ 成分)との 和に分解することができ，各成分の強度を $L_{p} ， L_{s}$ と 表すと,

$$
L(\lambda, i, e, g)=L_{p}(\lambda, i, e, g)+L_{s}(\lambda, i, e, g)
$$

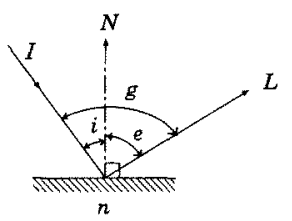

図 1 入射角 $i$, 反射角 $e$ ，位相 $g$ Fig. 1. Definition of incident ( $i$ ), emittance $(e)$, and phase $(g)$ angles.
また，2色反射モデルによると，反射光 $L$ は，表面 反射成分と内部反射成分との和に纷解することができ る。従って， $L_{\rho} お よ ひ ゙ L_{s}$ も，それそれ表面反射成 分と内部反射成分との和に分解できる。このうち，内 部反射成分は，媒質内の色素でランダムに散乱されて いると考えられるので，非偏光であると仮定すると， $L_{p}$ の内部反射成分強度 $L_{p b}$ と $L_{s}$ の内部反射成分強 度 $L_{s b}$ は等しく,

$$
\begin{aligned}
L_{p b}(\lambda, i, e, g) & =L_{s b}(\lambda, i, e, g) \\
& =\frac{1}{2} L_{b}(\lambda, i, e, g)
\end{aligned}
$$

従って， $L_{\rho}$ の表面反射成分強度を $L_{p i}, L_{s}$ の表面反 射成分強度を $L_{s i}$ と表すと， $L_{p}$ および $L_{s}$ は，

$$
\begin{aligned}
L_{p}(\lambda, i, e, g)= & L_{p i}(\lambda, i, e, g)+\frac{1}{2} L_{b}(\lambda, i, e, g) \\
& \ldots \ldots \ldots \ldots \ldots \cdots \cdots \cdots \cdots \cdots \cdots \cdots \cdots \cdots \cdots \cdots \cdots \cdots \cdots(3) \\
L_{s}(\lambda, i, e, g)= & L_{s i}(\lambda, i, e, g)+\frac{1}{2} L_{b}(\lambda, i, e, g)
\end{aligned}
$$

となる。2 色反射モデルによると，Lは幾何学的パ ラメータによる成分 $m_{i}(i, e, g)$ と分光分布の成分 $c_{i}(\lambda)$ との積に分解することができ, $c_{i}(\lambda)$ は入射光 $I(\lambda)$ の分光分布と等しく, $m_{i}(i, e, g)$ はその表面反射 係数である。反射の法則 ${ }^{(12)} よ り$, 表面反射では入射 角 $i$ と反射角 $e$ が等しく，また入射光と反射光は同 一面内にあるので位相角 $g$ は $\pi$ である。って， $m_{i}(i, e, g)$ は $e$ みの関数であるので, これを改めて $R(e)$ と表し, そのp成分を $R_{p}(e), s$ 成分を $R_{s}(e)$ とする。更に，入射光の $p$ 成分の強度を $I_{p}(\lambda), s$ 成

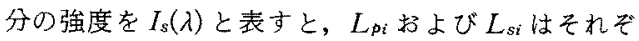
h,

$$
\begin{aligned}
& L_{p i}(\lambda, i, e, g)=\frac{1}{2} I_{p}(\lambda) R_{p}(e) \\
& L_{s i}(\lambda, i, e, g)=\frac{1}{2} I_{s}(\lambda) R_{s}(e)
\end{aligned}
$$

となる。いま, $I_{p}(\lambda)$ と $I_{s}(\lambda)$ の分光分布が等しいと 仮定し，定数 $\eta$ を，

$$
\eta=I_{p}(\lambda) / I_{s}(\lambda)
$$

とする。(3)〜 ( 7 )式から， $L_{p i}, L_{s i}, I_{p}(\lambda)$ および $I_{s}(\lambda)$ を消去すると,

$$
\begin{aligned}
& L_{b}(\lambda, i, e, g) \\
& \quad=2 \frac{L_{p}(\lambda, i, e, g)-\mu(e) L_{s}(\lambda, i, e, g)}{1-\mu(e)}
\end{aligned}
$$

ただし， 


$$
\mu(e)=\eta \frac{R_{p}(e)}{R_{s}(e)}
$$

が得られる。いま, 波長特性が $S(\lambda)$ の光学系と撮像 素子(以下，撮像系という)で撮像する場合を考え, (8)式の両辺に $S(\lambda)$ を掛けて $\lambda, i, g$ で積分すると,

$$
\begin{aligned}
\iiint L_{b}(\lambda, i, e, g) S(\lambda) d \lambda d i d g \\
=\iiint 2 \frac{L_{p}(\lambda, i, e, g)-\mu(e) L_{s}(\lambda, i, e, g)}{1-\mu(e)} \\
\quad \times S(\lambda) d \lambda d i d g \ldots \ldots \ldots \ldots \ldots \ldots \ldots \ldots(10)
\end{aligned}
$$

となる。(10)式において，

$$
\begin{aligned}
& \iiint L_{b}(\lambda, i, e, g) S(\lambda) d \lambda d i d g=C_{b}(e) \\
& \iiint L_{p}(\lambda, i, e, g) S(\lambda) d \lambda d i d g=C_{p}(e) \\
& \iiint L_{s}(\lambda, i, e, g) S(\lambda) d \lambda d i d g=C_{s}(e)
\end{aligned}
$$

と扝くと，内部反射成分 $C_{b}(e)$ は，

$$
C_{b}(e)=2 \frac{C_{p}(e)-\mu(e) C_{s}(e)}{1-\mu(e)}
$$

で表される。また，表面反射成分 $C_{i}(e)$ は, $C_{b}+C_{i}$ $=C_{p}+C_{s}$ であるので,

$$
C_{i}(e)=\left\{C_{s}(e)-C_{p}(e)\right\} \frac{1+\mu(e)}{1-\mu(e)}
$$

となる。

(11)，(12)式において， $C_{p}(e)$ および $C_{s}(e)$ は反射 光の特定方向の偏向成分を同一の波長特性 $S(\lambda)$ をも つ撮像系で撮像した結果であるので，面の法線 $N$ が わかれば測定可能な雗である。また, 係数 $\mu(e)$ は面 の法線 $N$ がわかれば計算可能である。往って, 面の 法線 $N$ がわが机，内部反射成分 $C_{b}(e)$ 坅よび表面 反射成分 $C_{i}(e)$ は，(11)，(12)式上り求められる。

〈2・2〉方 法 自律走行車の走行路面のよう に対象物が平らな誘電体で, その材質の届折率が既知 である場合について，前述の(11)，(12)式を使って内 部反射成分と表面反射成分の画像を求める方法を述心 る。

図2にこの場合の対象物と撮像系の関係を示す。こ こで, 撮像素子の向きは, 撮像素子上の画素の $x$ 軸 が対象物平面と平行であるとする。

まず，画像の座標 $(x, y)$ とそれに対応する反射角 $e$ との関係を示す。撮像素子の画素位置 $(x, y)$ に結像 されている物体上の点を $Q(x, y)$ とする。点 $Q(x, y)$ における反射角 $e(x, y)$ は, 点 $Q(x, y)$ とレンズの主 点とを結ぶ線が床面の法線 $N$ となす角度である。従 って, 座標 $(x, y)$ に対応する反射角 $e(x, y)$ は,

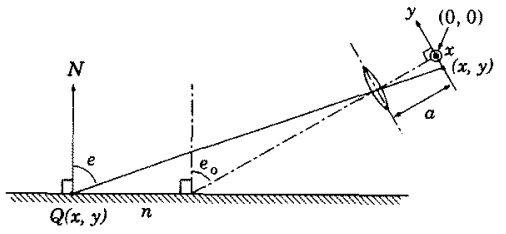

図 2 対象物と撮像系

Fig. 2. Object surface and the imaging system.

$$
\begin{aligned}
e(x, y)= & \cos ^{-1}\left\{\cos \left(\tan ^{-1} \frac{x D_{x}}{a}\right)\right. \\
& \left.\times \cos \left(e_{0}-\tan ^{-1} \frac{y D_{y}}{a}\right)\right\} .
\end{aligned}
$$

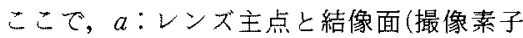
の受光面)との距離， $D_{x}, D_{y}$ : それぞれ撮像 素子の受光面での横方向および綐方向の画素 間隔

となる。なお，座標原点 $(0,0)$ は光軸の位置にとり， $e(0,0)$ を $e_{0}$ と表した。

一般に蛙, $x D_{x} \ll a, y D_{y} \ll a$ でるので，(13)式 は,

$e(x, y) \approx e_{o}-\frac{y D_{y}}{a}$

となる。

Fresnel の公式とSnell の法則より，p成分および $s$ 成分の光の丧面反射率は,

$$
\begin{aligned}
& R_{p}(e)=\frac{\tan ^{2}\left\{e-\sin ^{-1}(\sin e / n)\right\}}{\tan ^{2}\left\{e+\sin ^{-1}(\sin e / n)\right\}} \\
& R_{s}(e)=\frac{\sin ^{2}\left\{e-\sin ^{-1}(\sin e / n)\right\}}{\sin ^{2}\left\{e+\sin ^{-1}(\sin e / n)\right\}}
\end{aligned}
$$

である年。従って，座標 $(x, y)$ に対応する係数 $\mu\{e(x, y)\}$ は，(9)，(15)，(16)式ょり，

$$
\begin{aligned}
& \mu\{e(x, y)\} \\
& \quad=\eta \frac{\cos ^{2}\left[e(x, y)+\sin ^{-1}[\sin \{e(x, y)\} / n\}\right]}{\cos ^{2}\left[e(x, y)-\sin ^{-1}[\sin \{e(x, y)\} / n]\right]}
\end{aligned}
$$

である。ここで，通常の照明光は非偏光であるので， $\eta=1$ である。

一方，力メラの水平画角 $\theta_{x}$ が $\theta_{x} \ll 1$ であるとする と, 反射光の $p$ 成分 $C_{p}(e)$ の偏光面は $x$ によらず物 体面と直交すると近似できるので， $p$ 成分の面像 $C_{p}(x, y)$ と $s$ 成分の画像 $C_{s}(x, y)$ は, レンズの前に 偏光板を置き偏光板の向を2通りに変えて撮像する ことにより求められる。

従って，(11)，(12)式より,内部反射成分の画像 
$C_{b}(x, y)$ 扔よび表面反射成分の画像 $C_{i}(x, y)$ 注，

$$
C_{b}(x, y)=2 \frac{C_{p}(x, y)-\mu\{e(x, y)\} C_{s}(x, y)}{1-\mu\{e(x, y)\}}
$$

$$
\begin{aligned}
C_{i}(x, y)= & \left\{C_{s}(x, y)-C_{p}(x, y)\right\} \\
& \times \frac{1+\mu\{e(x, y)\}}{1-\mu\{e(x, y)\}} \cdots \cdots . . .
\end{aligned}
$$

によって計算することができる。なお，本方法では光 源の個数や配置などは計算するうえで必要とならな फ。

\section{3. 視覚システム}

波晶の電気光学的性質(13) 利用して, 反射光の各 偏光成分の画像 $C_{p}$ 抢よび $C_{s}$ を同一の撮像素子で順 次撮像できるようにして，動物体の検知に適用できる ような視賞システムを試作した。

図 3 に，試作した視覚システムの構成を示す。視覚 システムは，撮像部と処理部とから構成される。

撮像部は, 通常の CCD カメラのレンズの前に偏光 板と液晶セルを取り付けたものである。液晶セルは， 透明導電膜をコートしたガラス電極間に Nematic 液 晶を入れた Twisted Nematic 液晶セルで，電極間に 電圧を印加しない場合にはセルを通過した光の偏光面 が一定角度 $\omega$ だけ回転し，十分な電圧を印加した場 合には回転しないように構成されている。偏光板の向 きは， $p$ 成分すなわ磁界が物体の面に平行な偏光成 分を透過するように設定してある。液晶セルに十分な 電圧を印加したときは, 液晶セルに入射してきた光が 偏光面の回転を受けずに液晶七儿を通過するので，液 晶セルに入射してきた光の p成分が偏光板を透過し てカメラに入る。一方, 液晶セルに電圧を印加しない ときは，波晶セルに入射してきた光が液晶七ルを通過 する間に角度 $\omega$ たけ偏光面の回転を受ける。従って, このとき液晶セルに入射してきた光のうち $p$ 成

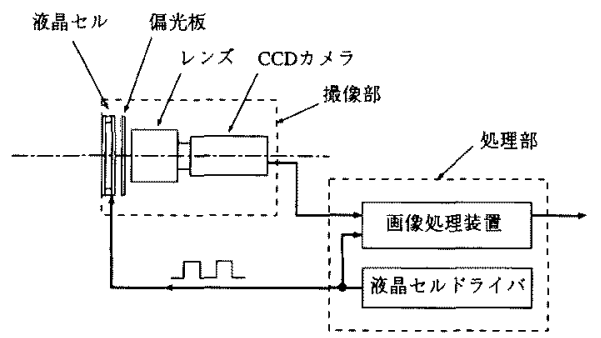

図 3 視覚システムの構成

Fig. 3. Configuration of the vision system for removing specular reflection component.
分が $\cos ^{2} \omega, s$ 成分が $\sin ^{2} \omega$ の割合で偏光板を透過し てカメラに入る。

よって, 電圧無印加時の画像を $C_{0}$, 電圧印加時の 画像を $C_{1}$ とすると, $p$ 成分の画像 $C_{p}$ および $s$ 成分 の画像 $C_{s}$ は,

$$
\begin{aligned}
& C_{p}=C_{1} \\
& C_{s}=\frac{C_{0}}{\sin ^{2} \omega}+\frac{C_{1}}{\tan ^{2} \omega}
\end{aligned}
$$

である。

処理部は, 液晶セルドライバで液晶セルへの印加電 圧を制御し， $\mathrm{CCD}$ カメラで画像 $C_{0}$ および $C_{1}$ を順次 撮像して，画像処理装置の画像メモりーに取り込み， 前述の方法で内部反射成分の画像を計算する。

なお，今回用いた液晶セルでは， $\omega=0.59 \mathrm{rad}$, 印 加電圧は $9 \mathrm{~V}$, 液晶セルの反応時間は常温で約 $60 \mathrm{~ms}$ である。

\section{4. 実 験}

〈4・1〉実験条件 試作した視賞システムの効果 確認と性能評洒のために, 以下の実験を行った。

図 4 に実駼装置を，図 5 に実験に用いた 2 種類の撮 像対象物(対象物 1 および対象物 2)を示す。視覚シス テムの撮像部は，图4に示すように位置決めした。対 像物は白色蛍光灯 $15 \mathrm{~W} 2$ 本入りの電気スタンドによ り照らされ，撮像部の位置から見たときに対象物表面 に光沢が発生する状況になっている。対象物 1 は, 黄

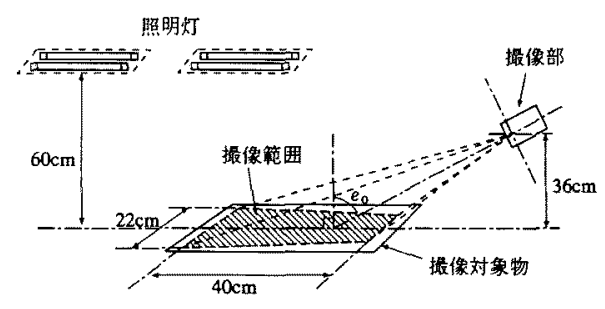

図 4 実験方法

Fig. 4. Experiment method.

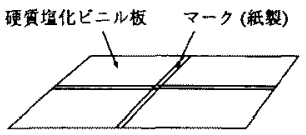

(a)

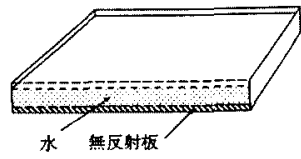

(b)
図 5 実験に用いた対象物 $1(\mathrm{a})$ と 対象物 2(b)

Fig. 5. Objects used for the experiment. 
色の硬質塩化ビニル $(n=1.55)$ 製の板上にマークとし て幅 $25 \mathrm{~mm}$ の紙製テープ（白色，表面は拡散反射的） を図のように張り付けたものである。対象物 2 は, 底 に無反射板を敷いた容器に水 $(n=1.33)$ を入れ, そ の反射光が表面反射成分のみであるようにしたもので ある。

なお, $a=26.7 \mathrm{~mm}, e_{o}=1.08 \mathrm{rad}, D_{y}=13 \mu \mathrm{m}$ で ある。照明光は非偏光であり $\eta=1$ である。以上の装 置を用いて以下の実験を行った。

（実験 1 ）対象物 1 を用い, 視覚システムによっ て表面反射成分が除去でき, 画像からマークが抽出で きることを確認する。

（実験 2 ）対象物 2 を用い, 視覚システムの表面 反射成分の除去性能を定量的に測定する。

\section{$\langle 4 \cdot 2\rangle$ 実験結果}

(実験 1) 図 6 に, カメラで撮像された画像 $C_{0}$ および $C_{1}$, 視覚システムの処理部で $C_{0}$ と $C_{1}$ とから 得られた内部反射成分の画像 $C_{b}$ および表面反射成分 の画像 $C_{i}$ を示した。あわせて, 撮像部の位置から通 常の TV メラによって撮像した場合の画像 $C$ も示 した。

同図から, 通常のカメラで撮像した面像 Cでは光 沢が発生しているのに対し，この視覚システムで得ら れた内部反射成分の画像 $C_{b}$ では光沢が除去されてい ることがわかる。このことから, この除去方法の効果 が確認された。

（実験 2 ）図 7 に視覚システムの表面反射成分の 除去性能の測定結果を示した。除去性能として, 全成 分のうち内部反射成分画像に残っている表面反射成分 量の割合を指標とした。すなわち, 視覚システムで得 られた画素 $(x, y)$ の内部反射成分を $C_{b}(x, y)$, 表面 反射成分を $C_{i}(x, y)$ とするとき，除去性能を示す指 標は,

$$
\frac{2 C_{b}(x, y)}{C_{b}(x, y)+C_{i}(x, y)}
$$

である。また破線は, カメラの前に単に偏光板を置い て撮像した画像 ( $C_{p}$ に相当)の場合の表面反射成分除 去特性

$$
\frac{2 C_{p}(0, y)}{C_{p}(0, y)+C_{s}(0, y)}
$$

の理論値を計算した結果を示す。

図 7 より, 本視覚システムにより表面反射成分をほ とんど分離することができ, TVカメラの前に単に偏 光板を置く場合に比べ十分に効果があることが示され た。なお， $x$ が 0 から離れると視覚システムの表面反 射成分除去特性が悪くなるのは, $x$ が 0 の位置では

電学論C, 113 巻 12 号, 平成 5 年

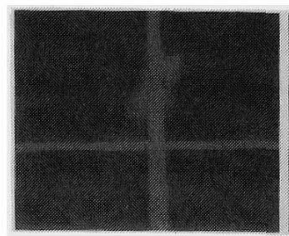

(a)

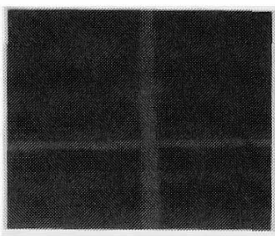

(c)

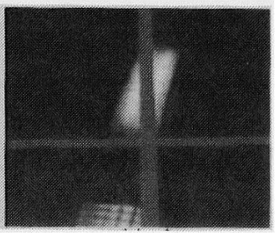

(b)

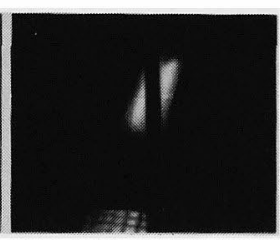

(d)

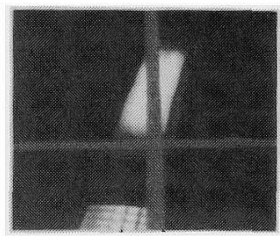

(e)

図 6 実験結果 1

Fig. 6. Result 1 : images of polarization component $C_{1}\left(=C_{p}\right) \quad$ (a), polarization component $C_{0}(\mathrm{~b})$, body reflection component $C_{b}(\mathrm{c})$, specular reflection component $C_{i}(\mathrm{~d})$ and by usual TV camera (e ).

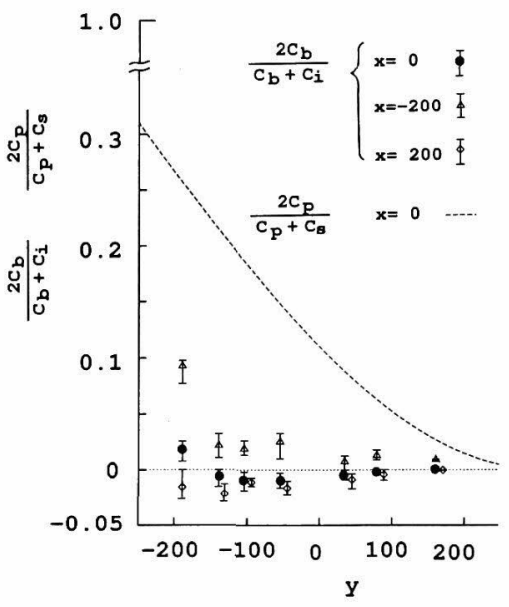

図 7 実験結果 2: 表面反射成分の除去性能 Fig. 7. Rusult 2 : specular reflection removal characteristic. 
$C_{p}$ の偏光面が対象物の面に完全に直交しているが, $x$ が 0 から離れるに従って完全な直交関係からわずか にずれるためである。

\section{5. 自律走行車の視覚への応用}

〈5・1〉構 成 本方式を用いた視覚システム を自律走行車の視覚部に応用した。図 8 に自律走行車 の構成を, 図 9 にその外観を示す。自律走行車は視賞 部, 認識部, 制御部からなり, 視覚部は前方の画像を 入力し, 認識部はその画像から白線を認識して白線位 置を算出する。制御部は, 白線位置情報をもとに舵と 車速の制御を行う。

図 10 にこの自律走行車が走行する環境を示す。自 律走行車は, 構内の床 (塩化ビニル製) に引かれた白線 に沿って走行する。床面は天井灯によって照明されて おり, 照明灯の反射で光沢が発生している。床は平面

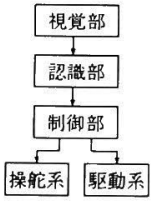

図 8 自律走行車の構成

Fig. 8. Configuration of vehicle.

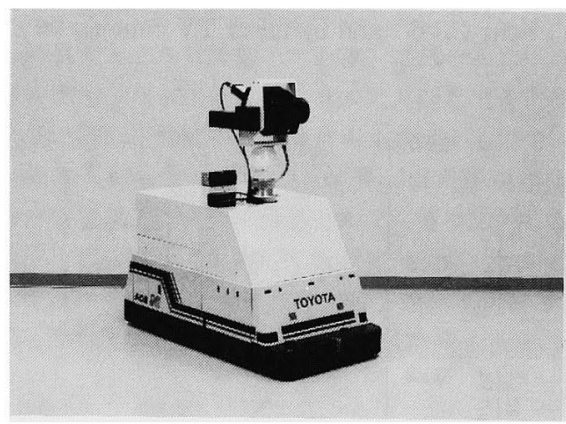

図 9 自律走行車の外観

Fig. 9. Vehicle.

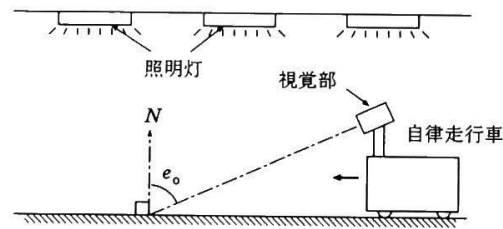

図 10 自律走行車の走行環境

Fig. 10. Vehicle and its environment.
であるため, 走行車が動いても，レンズ光軸と床の法 線とのなす角度 $e_{0}$ は一定に保たれる。

この自律走行車の視覚部に本視覚システムを用い, 内部反射成分の画像を使って認識部で白線を認識する ようにした。この自律走行車の諸元は表 1 に示すとお りである。

$\langle 5 \cdot 2\rangle$ 性 能 図 $11(\mathrm{a}),(\mathrm{b})$, 同一の場 面について, 走行車の視覚部として通常の TV カメ ラを用いた場合に得られた画像と, 本方式の視覚シス テムを用いた場合に得られた内部反射成分の画像とを 示す。図 11 の通常のカメラの画像では, 床の光沢の 影響のために，床の白線の一部が見えなくなっている ことがわかる。これに対し, 同図の視覚システムの画 像では, 通常のカメラの画像で問題となっていた床の 光沢が除去されており, 床の白線が明瞭に検出されて いる。

図 12 に通常のカメラの画像および本視覚システム

表 1 自律走行車の諸元

Table 1. Specifications of vehicle

\begin{tabular}{l|c}
\hline 走行速度 & $20 \mathrm{~cm} / \mathrm{s}$ \\
画像解像度 & $256 \times 256$ 画素 \\
撮像時間 & $200 \mathrm{~ms}$ \\
認識処理時間 & $100 \mathrm{~ms}$ \\
\hline
\end{tabular}

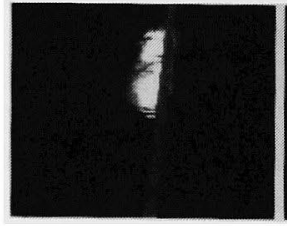

(a)

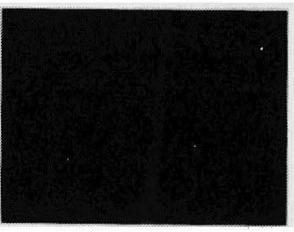

(b)
図 11 通常の TVカメラによる画像 (a) と 視覚システムによる内部反射成分画像 (b)

Fig. 11. Representative images by usual TV camera (a) and proposed vision system ( b ).

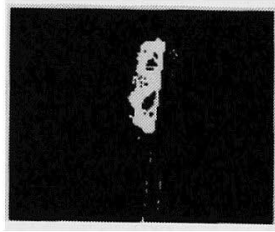

(a)

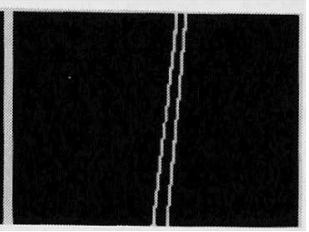

(b)
図 12 図 11(a), (b)の画像からの白線 抽出結果

Fig. 12. Line detection results from Fig. 11 (a) and (b). 
の画像のそれぞれに対して, 白線を抽出した結果を示 す。白線の抽出は, Sobel オペレータを施した後に判 別分析法によって二值化レベルを決定して二值化する ことにより行った。同図から，通常のカメラを用いた 場合には白線のエッジの一部しか抽出することができ ないのに対し, 本視覚システムを用いた場合には白線 のエッジが画像全体にわたって明瞭に抽出でき, 本方 式が有効であることがわかる。

\section{6. まと め}

2 色性反射モデルの仮定のもとに, 表面反射率が入 射光の偏光方向によって異なることを利用して，反射 光を表面反射成分と内部反射成分に分離する方法を提 案した。

そして，この方法に基づいて，液晶を用いて光沢を 除去できる視覚システムを試作し，その効果と性能を 示した。これを自律走行車の視覚に適用し, 光沢のあ る床面でも安定して白線が検出できることを示し, 提 案した方式の有効性を確認した。

(平成 5 年 4 月 30 日受付)

\section{文献}

（1）例えば，田村 編：コンピュー夕画像処理：応用実践編 2 , (平3) 総研出版

（2）例えば, 石川・淿波・小沢：「白線認識を利用した無人搬送 車における視賞誘導の一方式」，信学論、J69-D，580（昭 61-4)

（3）汪・加藤・佐藤・井口：「鏡面物体の 3 次元形状計測」, 同上, J75-D-I, 1177 (平 4-7)

（4）寺師・白井・越川：「偏光を用いた光沢物体の表面形状の認 識」，電総研重報，50, No. 1, 86（昭 61）

(5) L. B. Wolff: "Using polarization to separate reflection components", Proc. IEEE Comput. Soc. Conf. CVPR '89, p. 363 (1989)

(6) G. J. Klinker, S. A. Shafer \& T. Kanade: Using A Color Reflection Model to Separate Highlights From Object Color", Proc. of 1st Int. Conf. on Computer Vision, p. 145 (1987)

（7）橋本・加藤・森勝・佐藤・井口：「カラー画像を用いた材質 感の判別と相互反射の検出」, 信学論, J74-D-II, 727 (平 3-6)

(8) K Ikeuchi: "Determining the surface orientations of specular surfaces by using the photometric stereo method", IEEE Trans. Pattern Analysis \& Machine Intelligence, 3, No. 6, 661 (1981)
（9）西野・白井：「投影光学系を用いた光度差ステレオ法による 金属面の形状决定」，情処研報，CV 31-2（1984）

（10）西村・藤村・伊藤・喜女”「 $「 M$ 配列を用いた鏡面物体の三次 元形状計測」, 電学論 C, 112, 97 (平 4-2)

（11）漢野・中野・渡辺：「金属反射を持つ金属物体の面の認識」, 信学研资, PRU 87-83

（12）例えば, M. Born, et al.(草川, 他訳)：光学の原理 I (昭 49) 東海大学出版会

（13）例之ば，佐藤：液晶とその応用（昭 59）産業図書

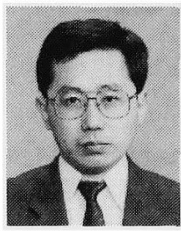

山田啓 一 (正員)

昭和 61 年名古屋大学大学院修士課程 修了。(株) 東芝を経て, 平成 3 年 (株) 豊 田中央研究所入社。以来, 自律走行車の 視覚に関する研究と開発に従事。現在, 同所システム 2 部所属。電子情報通信学会会員。

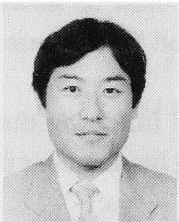

中 野 倫 明 (非会員)

昭和 57 年名古屋大学大学院修士課程 修了。同年(株)豊田中央研究所入社。以 来, 工業用文字認識, 三次元計測・認識 および自律走行車の視覚に関する研究と 応用装置の開発に従事。現在, 同所システム 2 部所属。工 学博士。電子情報通信学会, システム制御情報学会会員。

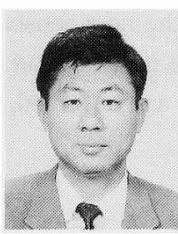

\section{山 本 新 (正員)}

昭和 40 年岐阜大学工学部電気工学科 卒業。同年(株)豊田中央研究所入社。以 来, 電気自動車の制御方式, 自動車にお ける電磁障害の計測技術, 画像処理を用 いた三次元計測・認識および自律走行車の視覚に関する研 究と開発などに従事。1984 年度 IEEE-VTS Paper Award 受賞。現在, 同所システム 2 部所属, 主席研究員。工学博 士。電子情報通信学会, 日本ロボット学会, 自動車技術会 会員。 